\title{
FATTY ACID COMPOSITION OF SULFATE-REDUCING BACTERIA ISOLATED FROM TECHNOGENIC ECOTOPES
}

\author{
D. R. ABDULINA, G. O. IUTYNSKA, L. M. PURISH \\ Danylo Zabolotny Institute of Microbiology and Virology, \\ National Academy of Sciences of Ukraine, Kyiv; \\ e-mail: adara@ukr.net
}

Received: 14 June 2019; Accepted: 15 May 2020

The growth of technogenic (man-caused) load on the environment leads to the disturbance of natural ecotopes and is a stress factor for the widespread sulfate-reducing bacteria (SRB). Changes of SRB fatty acid composition are considered to be not only one of the mechanisms of adaptation and protection from negative stress but also one of the chemotaxonomic features that can be used as the indicator of bacteria genus and its presence in natural ecotopes. The aim of the work was to determine the fatty acid composition of sulfatereducing bacteria strains isolated from different technogenic ecotopes. The spectrum of 17 fatty acids was determined by gas chromatography-mass spectrometry. The predominance of saturated C14:0, C15:0, C16:0 and C18:0 and the presence of unsaturated C16:1 and C18:1 fatty acids in SRB lipids were demonstrated. Correlation analysis showed that SRB isolated from the same technogenic locations were characterized by substantial similarity of fatty acid profiles despite belonging to different genera. Thus, fatty acid compositions of SRB strains Desulfovibrio sp. K1 and K2 isolated from soils near gas main-pipeline had correlation index $r=0.94$ and that Desulfovibrio sp. TC2, Desulfotomaculum sp. TC3 and Desulfomicrobium sp. TC4 isolated from city heat system ecotope had correlation index $r=0.97-0.99$. The obtained data on increased saturation degree of SRB fatty acids and decreased membrane fluidity indexes could be used for assessing the degree of $S R B$ adaptation to the influence of man-caused loading as a stress factor.

Ke y wo rds: fatty acid profiles, sulfate-reducing bacteria, ecotopes, correlation analysis.

$\mathrm{T}$ he growth of man-caused load on the environment leads to disruption of natural ecotopes and reveals as a stress factor for soil microbiota. In the areas of laying and exploitation of underground structures sulfate-reducing bacteria (SRB) are widespread. Adapting to environmental changes they are capable to reverse into corrosiverelevant modes [1]. Adaptation to stress factors is the subject of active research, in particular, attention is paid to study the fatty acid composition of bacterial cells.

The effect of technogenesis can lead to physiological and biochemical changes in the membranes of bacterial cells due to the fatty acid composition of cellular lipids. Such changes are one of the mechanisms of adaptation and protection of bacterial cells from negative stress factors [2, 3]. At the same time, the fatty acid composition of the bacterial total lipids is one of the chemotaxonomic features that can be used as an important indicator for identification. The study of the fatty acids profiles of 8 species of SRB belonged to Desulfovibrio and Desulfotomaculum genera had shown that lipid composition of these bacteria was quite different, it was noted significant heterogeneity on the species level [4]. Furthermore, there is suggestions about dominant fatty acids detection that they can be used as markers for detection of SRB presence in natural ecotopes. There was pointed that iso-heptadecenoic acid isoC17:1 can be used as a marker for identification of Desulfovibrio genus representatives. The comparison of SRB cultures on fatty acid profiles had shown that strains Desulfovibrio genus were characterized with a high content of branched and unsaturated fatty acids

(C) 2020 Abdulina D. R. et al. This is an open-access article distributed under the terms of the Creative Commons Attribution License, which permits unrestricted use, distribution, and reproduction in any medium, provided the original author and source are credited. 
and varied by saturated straight chain acids with different amount of carbon atoms. Significant number of studied Desulfovibrio strains had high content of isoC17:1 acid (up to $44.0 \%$ ), but some representatives of Desulfovibrio genus had small amount of this marker fatty acid (only 0-9.5\%). In other SRB strains were dominated anteiso-pentadecenoic acid anteisoC15:1 (30.0-54.0\%), at the same time in Desulfovibrio strains this acid was in minor amounts [5]. The comparative study of fatty acid content of the corrosive-relevant SRB isolated from various man-caused ecotopes in the zones of exploitation of underground industrial facilities had not conducted.

Recently, there is data lack about the effect of technogenesis on the fatty acid profiles of total bacterial lipids, but there is a lack of data about fatty acid analysis of SRB which exposed and isolated from different man-caused conditions, so the aim of the study was the determination of fatty acid composition of cell lipids of SRB, isolated from various man-caused ecotopes.

\section{Materials and Methods}

The objects of study were collection SRB strains, isolated from man-caused ecotopes: main gas-pipeline, city heat systems and reinforced concrete buildings. Desulfovibrio desulfuricans DSM642 (UCM B-11501), Desulfovibrio vulgaris DSM644 (UCM B-11502), obtained from the Deutch Collection (DSMZ). Bacterial strains Desulfovibrio sp. 10 (UCM B-11503), Desulfovibrio sp. TC2 (UCM B-11504), Desulfotomaculum sp. TC3 (UCM B-11505), Desulfomicrobium sp. TC4 (UCM B-11506) stores in the Ukrainian Collection of Microorganisms and Desulfovibrio sp. K1, Desulfovibrio sp. K2, Desulfotomaculum sp. K1/3 obtained from the collection of the Department of General and Soil Microbiology (Table 1).

Bacterial cultivation was performed in the liquid Postgate B medium, during 10 days at $28^{\circ} \mathrm{C}$. Initial amount of SRB cells was $10^{6}$ cells $/ \mathrm{ml}$. The determination of baterial amount were performed by the method of serial dillutions on liquid Postgate B media with subsequent caltulation (in cell per ml) with using of the MacCrady tables [7]. After cultivation to obtain bacterial biomass cultural liquid (45-50 ml) was centrifuged at $8000 \mathrm{rpm}, 20 \mathrm{~min}$ on centrifuge with rotor 5415R (Eppendorf).

Analysis of cellular fatty acid composition. The bacterial cells were washed twice from the cultural liquid residues with phosphate buffer $(6 \mathrm{nM}$ $\mathrm{K}_{2} \mathrm{HPO}_{4}, 2 \mathrm{nM} \mathrm{KH_{2 }} \mathrm{PO}_{4}, \mathrm{pH}$ 7.6). SRB biomass purification from ferric sulphides was carried out by $5 \%$ sodium citrate solution. Lipid components were removed from bacterial biomass with $5 \mathrm{ml}$ of $1.0 \% \mathrm{H}_{2} \mathrm{SO}_{4}$ solution in methanol [7]. Methyl esters of cellular fatty acids were separated on GC/MS Agilent $6890 \mathrm{~N} / 5973$ inert in gradient temperature mode from 150 to $250{ }^{\circ} \mathrm{C}$ [9]. Column HP-5MS, size $30 \mathrm{~m} \times 0.25 \mathrm{~mm} \times 0.25 \mu \mathrm{m}$, temperature program mode $-\left(4{ }^{\circ} \mathrm{C} / \mathrm{min}\right)$, carrier gas - helium, flow rate $1.2 \mathrm{ml} / \mathrm{min}$. The evaporator temperature $250{ }^{\circ} \mathrm{C}$; flow distribution was 1:100. Fatty acids were identified using the PC database and the standard mixture of the fatty acid methyl esters. The quantitative ratios of individual fatty acids were expressed as a percentage (\%) to total sum of fatty acids.

The unsaturation index was determined using formula [10]:

$$
\mathrm{UI}=\mathrm{A}+(2 \cdot \mathrm{B})+(3 \cdot \mathrm{C}) / 100
$$

where UI - is the index of unsaturation; $\mathrm{A}$ - the content of monounsaturated fatty acids, $\%$; B - content biunsaturated fatty acids, $\% ; \mathrm{C}-$ content triunsaturated fatty acids, $\%$.

The index of membrane viscosity was determined using formula [3]:

$$
\mathrm{I}_{\mathrm{VM}}=\mathrm{A}+\left(\mathrm{B}_{\text {trans }} / \mathrm{B}_{\mathrm{cis}}\right)+\mathrm{C} \text {, }
$$

where $\mathrm{I}_{\mathrm{VM}}$ - index of membrane viscosity; A - saturated fatty acids, $\%$; $\mathrm{B}_{\text {trans }}$ - content of trans-unsaturated fatty acids, $\%$; $\mathrm{B}_{\text {cis }}$ - content of cis-unsaturated fatty acids, \%; $\mathrm{C}-$ content of fatty acids with cyclopropane ring, $\%$.

The average carbon chain length of fatty acids was determined with formula [11]:

$$
\mathrm{L}=\Sigma(\mathrm{FA} \cdot \mathrm{C}) / 100 \text {, }
$$

where $\mathrm{L}$ - the average carbon chain length; $\mathrm{FA}$ - the content of fatty acid in cells, \%; C - the number of carbon atoms in the direct chain of fatty acid.

Correlation analysis was performed using Pearson's method to determine interval correlations. Pearson pair correlation coefficient was calculated using formula:

$$
r_{\mathrm{xy}}=\frac{\sum_{i=1}^{n}\left(x i-x^{-}\right) \cdot\left(y i-y^{-}\right)}{\sqrt{\sum_{i=1}^{n}\left(x i-x^{-}\right)^{2} \cdot\left(y i-y^{-}\right)^{2}}} .
$$

Full correlation was indicated as $r=1$, partial $0<r< \pm 1$; no correlation $r=0$ [12]. Statistical analysis of results was calculated using the arithmetic mean $(M \pm m, P<0.05)$ with MS Exel 2010 program software and Statistica ver. 10 (StatSoft Inc, USA, http://www.statsoft.com/). 
Ta b le 1. The studied SRB cultures

\begin{tabular}{|c|c|c|c|c|}
\hline № & Bacterial strain & Collection & The place of isolation & Reference \\
\hline 1 & Desulfovibrio vulgaris UCM B-11502 & DSM644 & Soil (DSMZ collection, Germany) & - \\
\hline 2 & $\begin{array}{l}\text { Desulfovibrio desulfuricans } \\
\text { UCM B-11501 }\end{array}$ & DSM642 & $\begin{array}{l}\text { Mixture of resin and sand near } \\
\text { the gas-pipeline in Great Britain } \\
\text { (DSMZ collection, Gernany) }\end{array}$ & - \\
\hline 3 & Desulfovibrio sp. 10 & $\begin{array}{c}\text { UCM } \\
\text { B-11503 }\end{array}$ & $\begin{array}{l}\text { Corrosion products of steel } \\
\text { construction of DniproHES, } \\
\text { Zaporizzhya, Ukraine } \\
\text { (UCM collection) }\end{array}$ & [6] \\
\hline 4 & Desulfovibrio sp. K1 & $*$ & \multirow{3}{*}{$\begin{array}{l}\text { Soil near surface of main gas- } \\
\text { pipeline “Souz” (IvanoFrankivsk } \\
\text { region, Ukraine) }\end{array}$} & \multirow[t]{3}{*}{ [7] } \\
\hline 5 & Desulfovibrio sp. K2 & * & & \\
\hline 6 & Desulfotomaculum sp. K1/3 & $*$ & & \\
\hline 7 & Desulfovibrio sp. TC2 & $\begin{array}{c}\text { UCM } \\
\text { B-11504 }\end{array}$ & \multirow{3}{*}{$\begin{array}{l}\text { Corrosion products and slime from } \\
\text { city heat systems (Kyiv, Ukraine) }\end{array}$} & \multirow{3}{*}{ [8] } \\
\hline 8 & Desulfotomaculum sp. TC3 & $\begin{array}{c}\text { UCM } \\
\text { B-11505 }\end{array}$ & & \\
\hline 9 & Desulfomicrobium sp. TC4 & $\begin{array}{c}\text { UCM } \\
\text { B-11506 }\end{array}$ & & \\
\hline
\end{tabular}

Notes: * Bacterial strains store at the collection of the Department of General and Soil Microbiology Danylo Zabolotny Institute of Microbiology and Virology NAS of Ukraine.

\section{Results and Discussion}

It is known that in response to physical and chemical environmental changes the protective mechanisms and metabolic adaptive reactions in bacterial cells may occur [13]. One of the mechanisms of bacterial adaptation to negative environmental factors is change the fatty acid composition of the lipid bacterial membranes and the unsaturation degree of cellular fatty acids $[11,14,15]$. Since collection SRB were isolated from various ecotopes i.e. main gas-pipeline, city heat systems and ironconcrete structure, and therefore previously were under different stress man-caused load, so comparative analysis of fatty acid composition of studied bacterial cell lipids was carried out.

The data obtained from fatty acid profiles analysis of total SRB lipids revealed spectrum from 17 fatty acids with total carbon chain length from 10 to 18 (Table 2).

In total SRB cell lipids fatty acids composition were 14 saturated and 3 unsaturated fatty acids. Next saturated fatty acids were detected in all strains (\%, of total acids): tetradecanoic C14:0 (2.08-8.69), hexadecanoic C16:0 (12.9-44.60\%) and octadecanoic C18:0 (1.20-4.72\%). Pentadecanoic acid C15:0 was prevealed in Desulfovibrio sp. K1 (30.35\%) and hexadecanoic nad octadecanoic acids in Desulfotomaculum sp. K1/3 (44.66\% and 4.72, respectively). Both strains were isolated from the same ecotope i.e. main gas-pipeline in Carpathians.

Unsaturated fatty acid hexadecenoic C16:1 (3.04-30.90\%) was found in the lipid composition of all studied SRB strains. Trans-octadecenoic transC18:1 (2.73-6.77\%) also were in all strains, excluding Desulfovibrio sp. 10, and cis-octadecenoic C18:1 was in small amounts in $D$. desulfuricans DSM642 and Desulfovibrio sp. TC2 and Desulfovibrio sp. K2 (1.08-1.93\%) and Desulfotomaculum sp. $\mathrm{K} 1 / 3(2.30 \%)$.

According to the fatty acid composition of lipids among bacteria of Desulfovibrio genus two strains were significantly differed such as $D$. desulfuricans DSM642, isolated from a mixture of resin and sand around the gas-pipeline (United Kingdom) and Desulfovibrio sp. 10, isolated from reinforced concrete corrosion products (DniproHES, Ukraine). In the fatty acid composition of $D$. desulfuricans DSM642 total lipids only 5 saturated and 3 unsaturated fatty acids as cis- and trans-octadecenoic C18:1 (1.93 and $2.73 \%$, respectively) and in significant amount hexadecenoic acid 16:1 (30.90\%) were revealed. In Desulfovibrio sp. 108 saturated and only 
Ta ble 2. The total lipids fatty acid compositions of SRB, \% from total content of fatty acids

\begin{tabular}{|c|c|c|c|c|c|c|c|c|c|c|}
\hline Fatty acid & $\begin{array}{l}\text { Chain } \\
\text { lengths }\end{array}$ & 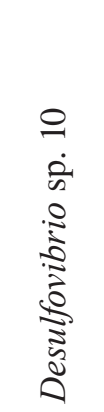 & 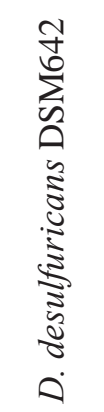 & 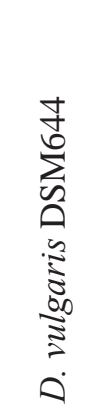 & 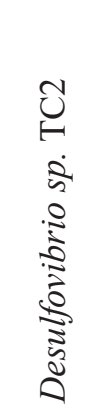 & 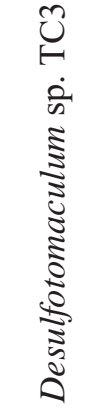 & 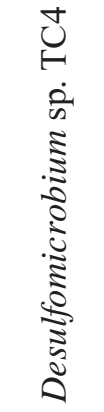 & 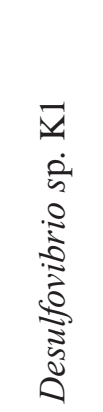 & 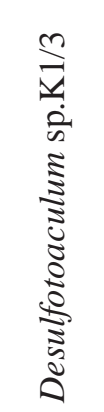 & 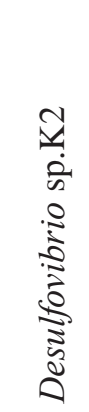 \\
\hline Decanoic & 10:0 & 1.73 & 0 & 0 & 0 & 0 & 0 & 0 & 0 & 0 \\
\hline Undecanoic & 11:0 & 0 & 0 & 0 & 3.64 & 0 & 0 & 0 & 0 & 0 \\
\hline Tridecanoic & 13:0 & 0 & 0 & 0 & 1.34 & 1.57 & 2.03 & 2.07 & 0 & 1.94 \\
\hline Tetradecanoic & $14: 0$ & 6.55 & 2.08 & 6.53 & 7.90 & 7.99 & 8.3 & 6.42 & 8.69 & 5.22 \\
\hline 3-hydroxytetradecanoic & OH14:0 & 0 & 0 & 6.99 & 0 & 0 & 0 & 0 & 0 & 0 \\
\hline Pentadecanoic & $15: 0$ & 26.87 & 0 & 16.52 & 23.73 & 27.01 & 27.83 & 30.35 & 0 & 19.91 \\
\hline iso-pentadecanoic & iso15:0 & 2.89 & 13.7 & 4.2 & 0 & 0 & 0.95 & 1.09 & 3.12 & 1.91 \\
\hline anteiso-pentadecanioc & aiso15:0 & 20.73 & 0 & 3.39 & 4.77 & 8.09 & 6.70 & 8.88 & 12.05 & 11.54 \\
\hline Hexadecanoic & $16: 0$ & 22.31 & 34.46 & 31.03 & 14.33 & 13.25 & 13.89 & 12.91 & 44.66 & 14.37 \\
\hline Hexadecenoic & $16: 1$ & 3.04 & 30.90 & 12.87 & 9.52 & 8.36 & 7.42 & 7.68 & 14.54 & 7.35 \\
\hline Heptadecanoic & $17: 0$ & 12.64 & 0 & 7.31 & 3.91 & 3.53 & 5.98 & 3.75 & 0 & 4.16 \\
\hline iso-heptadecanoic & $\mathrm{i} 17: 0$ & 0 & 10.55 & 2.26 & 0 & 0 & 0 & 0 & 0 & 0 \\
\hline cis,9,10 heptadecanoic & cis9,10 17:0 & 0 & 0 & 0 & 21.25 & 21.38 & 20.42 & 20.18 & 0 & 23.72 \\
\hline Octadecanoic & $18: 0$ & 3.18 & 3.62 & 4.44 & 1.71 & 1.89 & 1.20 & 1.17 & 4.72 & 2.22 \\
\hline Hydroxyoctadecanoic & $3 \mathrm{OH} 18: 0$ & 0 & 0 & 0 & 0 & 1.87 & 1.24 & 0 & 0 & 0 \\
\hline Cis-octadecenoic & cis18:1 & 0 & 1.93 & 0 & 1.08 & 0 & 0 & 0 & 2.30 & 1.32 \\
\hline Trans-octadecenoic & $\operatorname{trans} 18: 1$ & 0 & 2.73 & 4.40 & 6.77 & 5.00 & 3.98 & 5.43 & 3.38 & 6.29 \\
\hline
\end{tabular}

one unsaturated fatty acid hexadecenoic C16:1 in small amount (3.04\%) was revealed. Other SRB belonged to Desulfovibrio genus had minor differences in the fatty acid composition of cellular lipids.

According to the literature data, the lipids of anaerobic bacteria contain large amounts of iso- and anteiso branched fatty acids. The high content of these fatty acids founded in SRB of Desulfovibrio genus. It had reported that in $D$. africanus lipids the content of branched fatty acids was $30 \%$ as well as in D. gigas and D. desulfuricans strains was $57 \%$ and $61 \%$, respectively $[15,16]$. In our studied SRB isoand anteisoacids were appeared in small amounts. Only, in Desulfovibrio sp. 10 anteiso-pentadecanoic acid C15:0 was dominant in amount 20.73\%.

Bacteria Desulfotomaculum sp. TC3 and Desulfotomaculum sp. K1/3, isolated from various man-caused ecotopes, significantly differed in fatty acid profiles, although for phenotypic and phylogenetic characteristics were belonged to the same genus [8]. During determining of chemotaxonomic characteristics of bacteria of Desulfotomaculum genus performed by T.N. Nazina [17] it had shown that in the fatty acids spectra major fatty acids such as $\mathrm{C15:0}$ and $\mathrm{C17}: 0$, as well in fatty acid profiles of Desulfotomaculum strains were significant amount of C16:1 and C16:0 acids. In our work it were determined such isoacids as isoC15:0 (14.90-29.60\%), isoC17:0 (14.20-25.0\%), hexadecenoic C16:0 (24.10$26.60 \%)$ and octadecanoic C18:0 (16.7-22.4\%). However, in the studied fatty acids profiles of Desulfotomaculum genus iso-heptadecanoic acid iso17:0 was absent and iso-pentadecanoic acid isoC15:0 was detected only in Desulfotomaculum sp. K1/3 in small amounts $(3.12 \%)$. The result of comparing the fatty acid profiles of both strains was revealed that Des- 
ulfotomaculum sp K1/3 contained more unsaturated fatty acids as well as hexadecenoic and cis-, transoctadecenoic acids (only 20.23\%) and only 5 saturated fatty acids (69.88\%). Desulfotomaculum sp. TC3, in contrast, had 9 saturated (86.58\%) and only 2 unsaturated fatty acids (13.36\%). We noted that these SRB strains were isolated from various ecotopes with different conditions. In particular, Desulfotomaculum sp. TC3 was isolated from the heating systems site, which was operated for temperature of $60{ }^{\circ} \mathrm{C}$. There is evidence that due to influence of high temperatures in bacterial cell the content of saturated fatty acids had increasing. In particular, the increasing of the saturation degree of lipids due to high temperatures influence was found in the SRB cells of Desulfovibrio indonesiensis [18].

During the impact of heavy metal ions the increased saturation degree of lipids in bacterial cells was also observed. For example, due to influence of Cadmium, Nickel, Zinc and Cooper ions in cells of K. pneumoniae and Enterobacter intermedius the degree of lipid saturation had increased [19]. It was shown that the content of unsaturated fatty acids decreases in SRB cells due to the toxic effect of the stress factor i.e., increasing of ferric citrate content. From the other hand, the content of fatty acids with a branched carbon chain had increased to maintain the required level of cytoplasmic membrane fluidity [20]. There are assumptions that increasing of the content of saturated fatty acids with simultaneous decreasing the content of unsaturated fatty acids protects lipids from damages in the double bond sites [19].
Changes in the degree of saturation of fatty acids play an important role in the level membrane fluidity. Cytoplasmic membrane fluidity is the most important parameter determining cell survival under stressful conditions [15].

It is known that one of the mechanisms of bacterial adaptation to stress factors is to maintain an appropriate level of cytoplasmic membrane fluidity. This parameter had estimated by such indicators as the unsaturation degree of cell lipids, the bacterial membrane viscosity and the length of the fatty acid carbon chain [3, 21].

As compared with SRB of Desulfovibrio genus the indexes of cytoplasmic membrane fluidity confirmed that both strains Desulfovibrio sp. 10 and D. desulfuricans DSM642 significantly were differ from others, despite their belonging to the same genus. The unsaturation index for Desulfovibrio sp. 10 strain was the lowest among all the studied bacteria (0.03), because in fatty acid composition of this strain was only one unsaturated acid C16:1 (hexadecenoic). Instead in $D$. desulfuricans DSM642 the unsaturation index was 0.35 , the lowest viscosity membrane index (65.84) and the carbon chain length (9.28). The other bacteria of Desulfovibrio genus had similar indexes such as unsaturation degree (0.11-0.17) and index of membrane viscosity (107.06-113.50) (Table 3). We can suggest that difference in fatty acids profiles of studied strains of Desulfovibrio genus would be explained by their belongings to different species.

The features of the cytoplasmic membrane fluidity of studied bacteria of Desulfotomaculum genus were also significantly differed. Desulfoto-

Ta ble 3. The indexes of SRB from collections and isolated from man-caused ecotopes

\begin{tabular}{l|c|c|c}
\hline \multicolumn{1}{c|}{ Bacterial culture } & Unsaturation index, UI & $\begin{array}{c}\text { Index of membrane } \\
\text { viscosity, } \mathrm{I}_{\mathrm{VM}}\end{array}$ & $\begin{array}{c}\text { Average length of } \\
\text { carbon chain, L }\end{array}$ \\
\hline D. vulgaris DSM644 & 0.17 & 82.71 & $15.90 \pm 0.70^{*}$ \\
D. desulfuricans DSM 642 & 0.35 & 65.84 & $9.28 \pm 0.45$ \\
Desulfovibrio sp. 10 & 0.03 & 96.95 & $15.45 \pm 0.60$ \\
Desulfovibrio sp. K1 & 0.13 & 107.06 & $11.34 \pm 0.52$ \\
Desulfotomaculum sp. K1/3 & 0.26 & 77.55 & $8.79 \pm 0.34$ \\
Desulfovibrio sp. K2 & 0.15 & 113.50 & $9.74 \pm 0.45$ \\
Desulfovibrio sp. TC2 & 0.17 & 110.10 & $14.47 \pm 0.71$ \\
Desulfotomaculum sp. TC3 & 0.13 & 108.00 & $15.20 \pm 0.57$ \\
Desulfomicrobium sp. TC4 & 0.11 & 109.00 & $16.04 \pm 0.78$ \\
\hline
\end{tabular}

Note: $* \mathrm{~N}=17, P<0.05$ 
maculum sp. K1/3 had unsaturation degree (0.26), index of membrane viscosity (77.55) and the lowest average length of the carbon chain from all the studied strains (8.79). In contrast, the fluidity of the cytoplasmic membrane Desulfotomaculum sp. TC3 was differed in almost 2 times: the index of unsaturation (0.13), the membrane viscosity index (108.0) and twice longer carbon chain (15.20). Similar to the strain Desulfotomaculum sp. TC3 indicators of the degree of unsaturation, membrane viscosity index and carbon chain length were determined in Desulfomicrobium sp. TC4.

According literature data it is known that increasing the content of fatty acids with short chain leads to increasing the fluidity of the cytoplasmic membrane [21]. Other mechanisms of membrane fluidity regulation are also described, in particular, shortening or lengthening of the fatty acid chain, changes in the content of fatty acids with branched carboxylic chain or fatty acids that contain cyclopropane ring, and isomerization of the double bond of fatty acids with cis/trans configuration [11].

To compare the fatty acid profiles of SRB isolated from various ecotopes and belonging to different taxonomic positions a correlation analysis with calculating of Pearson's indexes was carried out (Table 4). Correlation analysis of the fatty acids profiles of collection SRB strains conducted by M. B. Vanstein was shown that the values of the indexes $r$ were under different conditions of cultivation of the same SRB strain $(r=0.99)$; for different strains of the same species $(r=0.98)$ and for close species of the same genus $r$ values were 0.94-0.96. The using of correlation indexes for comparison of SRB strains allows us evaluates not only qualitative coincidences for the presence of the same compounds, but quantitative using their concentration [5].

According to obtained from correlation analysis data of fatty acid profiles of Desulfovibrio sp. K1 and Desulfovibrio sp. K2 isolated near the main gaspipeline zone were similar with a correlation indexes $r=0.94$. The fatty acid profile of Desulfotomaculum sp. K1/3 strain was differed from mentioned above strains significantly (the correlation indexes were $r=0.27-0.37$, respectively), but this strain was similar to collection strains $D$. desulfuricans DSM642, D. vulgaris DSM644 with indexes 0.79 and 0.81 , respectively. As well as Desulfotomaculum sp. K1/3 mentioned above collection strains were also isolated from the samples collected near the main gas-pipeline. So we could suggest that similarity of the fatty acid profiles depends not only from taxonomic position, but also from ecotope of strain isolation.

Despite the fact that Desulfovibrio sp. TC2, Desulfotomaculum sp. TC3 and Desulfomicrobium sp. TC4 strains, isolated from same man-caused location, i.e. city heat systems were belonged to different genera they revealed high similarity $(r=0.97-0.99)$. Desulfotomaculum sp. TC3 and Desulfomicrobium sp. TC4 strains almost did not differ in fatty acid composition and membrane fluidity, their similarity were $r=0.99$. Thus, sulfate-re-

Ta b le 4. Data of correlation analysis of SRB fatty acids profiles

\begin{tabular}{|c|c|c|c|c|c|c|c|c|c|}
\hline \multirow{3}{*}{ Bacterial culture } & \multirow{2}{*}{\multicolumn{3}{|c|}{ Collection strains }} & \multicolumn{6}{|c|}{ Strains from man-caused ecotopes } \\
\hline & & & & \multicolumn{3}{|c|}{ city heat systems } & \multicolumn{3}{|c|}{ main gas-pipeline } \\
\hline & 10 & 642 & 644 & $\mathrm{TC} 2$ & TC3 & TC4 & K1 & $\mathrm{K} 1 / 3$ & $\mathrm{~K} 2$ \\
\hline Desulfovibrio sp. 10 & 1.00 & 0.28 & 0.74 & 0.61 & 0.67 & 0.70 & 0.71 & 0.54 & 0.64 \\
\hline D. desulfuricans DSM642 & - & 1.00 & 0.74 & 0.27 & 0.20 & 0.20 & 0.18 & 0.79 & 0.24 \\
\hline D. vulgaris DSM644 & - & - & 1.00 & 0.59 & 0.56 & 0.59 & 0.56 & 0.81 & 0.53 \\
\hline Desulfovibrio sp. TC2 & - & - & - & 1.00 & 0.98 & 0.97 & 0.96 & 0.34 & 0.95 \\
\hline Desulfotomaculum sp. TC3 & - & - & - & - & 1.00 & 0.99 & 0.99 & 0.30 & 0.96 \\
\hline Desulfomicrobium sp. TC4 & - & - & - & - & - & 1.00 & 0.99 & 0.29 & 0.94 \\
\hline Desulfovibrio sp. K1 & - & - & - & - & - & - & 1.00 & 0.27 & 0.94 \\
\hline Desulfotomaculum sp. K1/3 & - & - & - & - & - & - & - & 1.00 & 0.37 \\
\hline Desulfovibrio sp. K2 & - & - & - & - & - & - & - & - & 1.00 \\
\hline
\end{tabular}

Note: significant correlations are marked as regular black $(r>0.4, P<0.05)$, non-significant $(r \leq 0.4)$ as bold black. 
ducing bacteria had isolated from same man-caused locations despite their belonging to different genera determined by phenotypic and phylogenetic features were characterized with high degree of similarity in fatty acid profiles.

It was studied the fatty acid composition of total lipids of SRB, isolated from man-caused ecotopes. It was shown that SRB were characterized with high saturation degree of fatty acids, which indicates on the rigidity of the cell wall. Changing the saturation degree of cellular lipids is an important mechanism for maintaining the required level of fluidity of the cytoplasmic membrane and, accordingly, the adaptation of microorganisms to unfavourable environmental factors. The differences in fatty acid composition of SRB were due to decreasing the cytoplasmic membrane fluidity. The decreasing of cytoplasmic membrane fluidity is a protective adaptation reaction of bacteria to unfavourable conditions of existence. The fatty acid composition of total lipids and cytoplasmic membrane fluidity indexes can be serving as an important feature for assessing the degree of SRB adaptation to the influence of man-caused loading as a stress factor. Conducted correlation analysis of the fatty acid profiles had shown that SRB, which isolated from the same man-caused ecotopes had high similarity degree. Desulfovibrio sp. K1 and K2 strains, isolated from soils near gas main-pipeline had correlation indexes $r=0.94$; and SRB strains Desulfovibrio sp. TC2, Desulfotomaculum sp. TC3 and Desulfomicrobium sp. TC4, isolated from heating systems had correlation indexes $r=0.97$ 0.99. Obtained results are indicates about adaptation of the SRB to man-caused loading.

Further studies of fatty acids profiles of corrosive-relevant SRB isolated from different ecotopes can be ecologically useful for detection of cites with high level of corrosion danger.

Conflict of interest. Authors have completed the Unified Conflicts of Interest form at http://ukrbiochemjournal.org/wp-content/uploads/2018/12/coi disclosure.pdf and declare no conflict of interest.

The research was carried out within the framework of the project of the National Academy of Sciences of Ukraine "Functional activity and prospects of use in biotechnology soil microorganisms from natural, man- caused and agro systems" (20162019), State registration number GDR $0116 U 006319$.
Acknowledgments. The study of fatty acids profiles were provided with usage of equipment of the Centre of Collective Usage NAS of Ukraine Danylo Zabolotny Institute of Microbilogy and Virology NAS of Ukraine. We are grateful to Ostapchuk A.M. $(\mathrm{PhD})$ for the help and assistance in the analysis.

ЖИРНОКИСЛОТНИЙ СКЛАД
СУЛЬФАТВІДНОВЮЮАЛЬНИХ
БАКТЕРІЙ, ВИДІЛЕНИХ
І3 ТЕХНОГЕННИХ ЕКОТОПІВ

Д. Р. Абдуліна, Г. О. Іутинська, Л. М. Пуріш

Інститут мікробіології і вірусології ім. Д. К. Заболотного НАН України, Київ; e-mail: adara@ukr.net

Зростання техногенного навантаження на навколишне середовище призводить до порушення природних екотопів і $є$ стресовим чинником для широко поширених сульфатвідновлювальних бактерій (СВБ). Зміна жирнокислотного складу СВБ вважається не тільки одним із механізмів адаптації та захисту від негативного впливу, а й однією з хемотаксономічних ознак, які можуть бути використані як індикатор типу бактерій і присутності їх у природних екотопах. Метою роботи було визначення жирнокислотного складу сульфатвідновлювальних штамів бактерій, виділених із різних техногенних екотопів. Спектр 17 жирних кислот визначали методом мас-спектрометрії на газовому хроматографі. Показано, що в ліпідах СВБ переважали насичені C14:0, C15:0, C16:0 та C18:0 і були наявні ненасичені C16:1 та C18:1 жирні кислоти. Кореляційний аналіз виявив, що СВБ, виділені 3 тих самих техногенних локацій мають подібні профілі жирних кислот, незважаючи на приналежність до різних типів. Так, коефіцієнт кореляції жирнокислотного складу СВБ штамів Desulfovibrio sp. K1 і К2, виділених із грунтів, прилеглих до газопроводу, становив $r=0,94$, а для Desulfovibrio sp. TC2, Desulfotomaculum sp. TC3 i Desulfomicrobium sp. TC4, виділених is тепломереж, $r=0,97-0,99$. Одержані результати щодо підвищення рівня насичення жирних кислот і зниження плинності мембрани СВБ можуть бути використані для оцінки ступеня адаптації СВБ до впливу техногенного навантаження як стресового чинника. 
К л юч о в і сл ов а: профілі жирних кислот, сульфатвідновлювальні бактерії, екотопи, кореляційний аналіз.

\section{References}

1. Andreyuk KI, Kozlova IP, Kopteva ZhP, Pilyashenko-Novokhatny AI, Zanina VV, Purish LM. Microbial corrosion of underground constructions. Kyiv: Naukova Dumka, 2005. 260 p. (In Ukrainian).

2. Johnson MS, Zhulin IB, Gapuzan ME, Taylor BL. Oxygen dependent growth of the obligate anaerobe Desulfovibrio vulgaris Hildenborough. J Bacteriol. 1997; 179(17): 5598-5601.

3. Baysse C, O'Gara F. Role of membrane structure during stress signalling and adaptation in Pseudomonas. Pseudomonas. 2007; 7: 193-224.

4. Ueki A, Suto T. Cellular fatty acid composition of sulfate-reducing bacteria. J Gen Appl Microbiol. 1979; 25(3): 185-196.

5. Vainshtein MB, Gogotova GI, Galushko AS. Grouping of sulfate-reducing bacteria by spectral properties of cytochrome c. Mikrobiologiya. 1996; 65(2): 160-164. (In Russian).

6. Asaulenko LG, Abdulina DR, Purish LM. Taxonomic position of certain representatives of sulphate-reducing corrosive microbial community. Mikrobiol Zhurn. 2010; 72(4): 3-10. (In Ukrainian).

7. Abdulina DR, Purish LM, Iutynska GO. Microbial communities and sulphate-reducing bacteria in soils near main gas-pipeline. Mikrobiol Zhurn. 2018; 80(5): 3-14.

8. Purish LM, Asaulenko LG, Abdulina DR, Iutinskaia GA. Biodiversity of sulfate-reducing bacteria growing on objects of heating systems. Mikrobiol Zhurn. 2014; 76(3): 11-17. (In Russian).

9. Varbanets LD, Zdorovenko GM, Knirel YuA. Methods of endotoxins investigation. K.: Naukova Dumka, 2006. 238 p. (In Russian).

10. Guerzoni ME, Lanciotti R, Cocconcelli PS. Alteration in cellular fatty acid composition as a response to salt, acid, oxidative and thermal stresses in Lactobacillus helveticus. Microbiology. 2001; 147(Pt 8): 2255-2264.

11. Härtig C, Loffhagen N, Harms H. Formation of trans fatty acids is not involved in growth-linked membrane adaptation of Pseudomonas putida. Appl Environ Microbiol. 2005; 71(4): 1915-1922.

12. Kupalova HI. The theory of economic analysis. Mannual. Kyiv, 2008. 639 p. (In Ukrainian).
13. Denich TJ, Beaudette LA, Lee H, Trevors JT. Effect of selected environmental and physicochemical factors on bacterial cytoplasmic membranes. J Microbiol Methods. 2003; 52(2): 149-182.

14. Duldhardt I, Gaebel J, Chrzanowski L, Nijenhuis I, Härtig C, Schauer F, Heipieper HJ. Adaptation of anaerobically grown Thauera aromatica, Geobacter sulfurreducens and Desulfococcus multivorans to organic solvents on the level of membrane fatty acid composition. Microbial Biotechnol. 2010; 3(2): 201-209.

15. Murínová S, Dercová K. Response mechanisms of bacterial degraders to environmental contaminants on the level of cell walls and cytoplasmic membrane. Int J Microbiol. 2014; 2014: 1-16.

16. Boon JJ, de Leeuw JW, Hoek GJ, Vosjan JH. Significance and taxonomic value of iso and anteiso monoenoic fatty acids and branched $\beta$-hydroxy acids in Desulfovibrio desulfuricans. J Bacteriol. 1977; 129(3): 1183-1191.

17. Nazina TN, Turova TP, Ivanova AE, Belyaev SS, Poltaraus AB, Gryadunov DA, Osipov GA. Phylogenetic position and chemotaxonomic characteristics of the thermophilic sulfatereducing bacterium Desulfotomaculum kuznetsovii. Mikrobiologiya. 1999; 68(1): 92-99. (In Russian).

18. Fichtel K, Logemann J, Fichtel J, Rullkötter J, Cypionka H, Engelen B. Temperature and pressure adaptation of a sulfate reducer from the deep subsurface. Front Microbiol. 2015; 6: 10781.

19. Markowicz A, Plociniczak T, PiotrowskaSeget Z. Response of bacteria to heavy metals measured as changes in FAME profiles. Polish $J$ Environ Stud. 2010; 19(5): 957-965.

20. Maslovska O, Hnatush S, Halushka A. Fatty acids composition of Desulfuromonas acetoxidans IMV B-7384 cells under the influence of ferric citrate. Studia Biologica. 2014; 8(3-4): 87-98. (In Ukrainian).

21. Mazzella N, Syakti AD, Molinet J, Gilewicz M, Doumenq P, Artaud J, Bertrand JC. Effects of crude oil on phospholipid fatty acid compositions of marine hydrocarbon degraders estimation of the bacteria membrane fluidity. Environ Res. 2005; 97(5): 300-311. 